\title{
Litigation Services and Fraud Cases: Perspective of the Forensic Accountant
}

\author{
Enofe, A. O. Ochei, I. M. Emecheta, C. V Oyibo, O. D. \\ Department of Accounting, Faculty of Management Sciences, University Of Benin, Benin City, Edo State
}

\begin{abstract}
The study examines the role and effect of the forensic accountant's litigation services in the adjudication of fraud cases. Data was gathered mainly by applying a structured questionnaire to a target sample for respondence, as well as interviewing respondents and noting their responses. The target population included legal practitioners and accountants, both of which were randomly selected; 20 respondents each, based on our set criteria of knowledge of subject matter. Descriptive of the responses was first gotten, after which a reliability test was carried out on our instrument of measurement for which we got 0.78 using Cronbach's Alpha, confirming the internal consistency of our instrument. We went further to test our hypothesis using a one sample T- Test, which revealed that the forensic accountant's litigation services does affect the adjudication of fraud cases. The study therefore recommends especially for developing countries like Nigeria, to fully standardize, structure and improve the use of forensic accountants in the adjudication fraud cases as we believe this will increase the chances of getting convictions.
\end{abstract}

Keywords: Forensic Accounting, Fraud Cases, Litigation, Prosecution, Expert witness, Special Masters, Expert consultant

\subsection{Introduction}

While the word "fraud" may not be new to many, over time there have been a lot of effort to understand its implications, detection as well as prevention and prosecution (Enofe, Okpako \& Atube, 2013; Okoye \& Gbegi, 2013; Olukowade \& Balogun, 2015). Fraud as defined by Enofe, Julius \& Ogbeide (2015), is the intentional misrepresentation of material fact to gain some form of advantage over a victim. While the accountant may not be the most fit authority to ascertained the social or behavioral reasons for fraud, his experience over time and practice has made eminent his role in fraud detection, prevention and prosecution (Enofe et. al., 2015).

A lot of effort has been put into fraud detection and prevention over the years. This may be credited to the negative effects of fraud that has been suffered by individuals, corporate bodies and even governments. The Association of Certified Fraud Examiner (ACFE, 2016), reported that the most common fraud prevention as well as detection mechanism adopted by companies include; external audit of financial statement, management certification of financial statement and code of conduct. It asserted that these were measures taken due to the high level of fraud and fraud related activities. The ACFE (2016) also reported that losses to fraud and fraudrelated activities between years 2014 to 2015 was about \$ 6 billion; and the report was of a survey done in 114 countries alone. The figure doesn't come as much of a surprise as there has been an upsurge in fraud and fraudrelated cases over the years (Sanchez \& Zhang, 2012; Modugu \& Anyaduba, 2013; Papoola, Che-Ahmed \& Samsudin, 2014; Elukowade \& Balogun, 2015; Enofe et. at., 2015). Financial Fraud Action Uk (FFA, 2015) in its report put the amount of losses reported on UK issued cards at over five hundred million pounds. The Federal Bureau Investigation (FBI, 2015) puts the amount lost to fraud to in Billions of Dollars yearly. These numbers are still on the rise despite numerous fraud prevention and detection controls put in place. While there may be some difficulty in measuring the effect of preventive and detective measures in monetary values accurately, some have alluded that these measures have been effective (Enofe et al., 2013 Modugu \& Anyaduba, 2013), however little is said about the effect of successful prosecution of fraud cases. The FBI (2012) says it secured over 600 convictions leading to recoveries of about $\$ 23$ billion. If that much can be recovered in areas of FBI jurisdiction, one can only imagine how much would be recovered outside their Jurisdiction. In Nigeria, the reports of fraud and fraud related cases are predominant in the dailies, billions of naira lost to all kinds of fraudulent schemes both in the private and public sectors (Dada, Owolabi \& Okwu, 2013; Modugu \& Anyaduba, 2013). There is a need therefore to detect, prevent as well as successfully prosecute fraud (Dada, et. al. 2013).

The forensic accountant's role is unquestionably important in fraud detection and prevention; it is also copiously relevant for prosecution of fraud cases (Azih \& Okoli, 2015; Enofe et. al., 2013). Enofe et. al. (2013) suggested that fraud incidences are contributory to the growing demand for the forensic accountant's skill set and technical knowhow. This position was echoed by Modugu and Anyaduba (2013) as well as Azih and Okoli (2015). The scope of the study was however limited to forensic accountants role in prosecuting fraud cases, particularly litigation services except conflict resolution or Alternative Dispute Resolution services. In order words, we are concerned with Trial and post-trial related matters. American Institute of Certified Public Accountants (AICPA, 2007), stated that the litigation services as undertaken by the forensic accountants include his services as a consultant, expert witness and special master. Our objective therefore is to examine the effect of 
these roles if any on the adjudication of fraud cases.

We would therefore be testing the following hypothesis;

Ho1; $\quad$ Forensic Accounting Consultant services does not affect fraud cases

Ho2; $\quad$ Forensic Accounting Expert Witness service does not affect fraud cases

Ho3; Forensic Accounting Special Masters service does not affect fraud cases

We believe successful prosecution of fraud cases will not only lead to recoveries, but also expose peculiar fraud schemes therefore help management, government, business owners and employers come up with better ways of fraud detection and more importantly, fraud prevention. This may also set the ball rolling for other empirical and non-empirical researches to cover the limitations in scope; sample size, composition and so on.

\subsection{Review of literature \\ 2.1 Fraud Cases}

Cases as used in the context of this paper refer to litigation or court cases. Fraud on the other hand has a larger implication. Due to its complexity; fraud is as difficult to fully define as it is to identify (Enofe, et. al., 2013). Enofe et al. (2013) had a go at defining fraud, they suggested that it involved surprise or cunning ways of presenting or misrepresenting truth, intentionally to deceive or manipulate a company or individuals to enrich oneself. Furthermore, they made a fuel spark and oxygen analogy, where the components that may give way to fraud being committed were given as pressure, opportunity and justification also known as fraud triangle.

Okoye and Gbegi (2013) recount of Black's law Dictionary (1979) supported the above definition by defining fraud to include means resorted to by "individual to get an advantage over another by false suggestions...includes surprises, tricks, cunning or dissembling, and any unfair way by which another is cheated". Popoola, Che-Ahmed and Samsudin (2014) further affirmed the elements of fraud to include; intentional misrepresentation or material facts, deception and gains to fraudster or loss to victim.

Having touched on the components and elements of fraud, it would help give an insight on what may constitute fraud, that is to say we may better identify what falls within the scope of fraud to be; intentional material misstatements carried out through deception inherent by the existence of pressure, opportunity and justification thereby causing loss or damage to victim and gain to perpetrator or fraudster. The effect of fraud both in private and public sectors is undeniably huge (Okoye \& Gbegi, 2013; Owolabi \& Ukwu, 2013; ACFE, FFA, 2015; 2016; Dada)

\subsection{Forensic Accountant}

There is no known literature evidence supporting one particular person or group as the sole group or body responsible for fraud detection or prevention. There are suggestions however that forensic accountant could be an important part of fraud detection, prevention and persecution of fraud cases (Modugu \& Anyaduba, 2013; Okoye \& Gbegi, 2013; Ehioghiren \& Atu, 2016). A close look at the concept of the forensic accounting indicates that it's a mishmash of accounting and forensic, in other words to; collect, analyze, interpret, summarize and present finance and business-related issues and; present same in a manner acceptable for court use (Dada et. al., 2013). According to Dada, et. al. (2013), forensic accounting is the integration of accounting, auditing and investigative skills in detecting and setting up prevention against fraud and fraud-related activities, as well as gathering admissible evidence for court use, which we may infer to be the aspect dealing with prosecution of fraud cases (Okoye \& Gbegi, 2013). Okoye and Gbegi (2013) emphasize on the need for skills or technical know-how in carrying out the forensic accountant's duties, and implied that IT skills, investigative or detective skills as well as a good knowledge of court system, processes, evidence gathering and so on, in addition to his accounting knowledge or background are all important.

As far as litigation services go, the forensic accountant may play any of three major roles; consultant, expert witness and special masters (Muehlmann, Burnaby \& Howe, 2012; AICPA, 2014; Okoye \& Gbegi, 2013). These roles will form the basis of our analysis. Adeleh (2014) opined that judges and lawyers were only legal experts and not accounting experts, making judging accounting issues a problem as having to connect evidence or proof materials to facts would require the specialist or professional knowledge of the forensic accountant. According to him, the forensic accountant is to apply his professional knowledge and convert relative information into content that are easily understood by the court and establish a bridge for the courts' reasoning.

\subsection{Litigation Services}

Litigation services according to AICPA (2007) include; preparing company codes of business ethics and conduct, proactive fraud auditing, assessing risks associated with fraud and illegal acts, evaluating the strength or efficiency of internal control, laying out and implementing internal control systems and procedures, developing compliance programs for body corporates and consulting about employee relations or bonding.

2.3.1 Forensic Accounting Consultant; As a consultant, the forensic accountant is required to employ his skills in working for a litigating party in capacities ranging from facts finding; which involves assisting in the 
discoveries phase of litigation and analysis of data; damages calculations, document management and preparation of demonstrative evidence and so on (AICPA, 2007). According to AICPA, all the aforementioned duties may also be given as expert witness or testimony; however, the forensic account need not give an expert witness or be directly involved in court proceedings when acting purely as a consultant. Golden, Dyer and Andreassen (2006) suggested that some circumstances where the forensic accountant may be expected to work with or for an attorney include; internal investigation in relation to reporting matters that may have been red flagged by tips, internal audit or audit committee concerns, external auditor findings or reports from media or regulatory reports. Other circumstances may include regulatory investigations, tax authority subpoenas and civil litigation such as contract issues, shareholder lawsuits, fraud recovery actions and so on. In cases involving fraud he may be brought in to investigate, analyze or throw lights on accounting issues by an attorney on either side of a dispute. The forensic accountant may work with or for the defendant in a case or a government agency prosecuting a fraud case (Golden et. al., 2006). According to Hopwood, Young and Leiner (2013), the investigative skill of the forensic accountant is very important in his expert consultant role. The investigation process involves gathering and review of evidence that is, the engagement, evidence collection, reporting and loss recovery processes. They suggested that evidence in this case may be physical evidence, document evidence, observation evidence and interview evidence.

Elmore, D. (2016) analogy of the role of the expert consultant goes thus:

He likened the job of the expert consultant to that of a doctor or mechanic, an individual hired for his or her expertise and experience in unfamiliar areas, to the attorney. In cases involving economic damages and accounting analyses, a consultant's highly specialized area of expertise or technical knowhow can be invaluable to the lawyer trying to understand the bulk of paperwork, interpret a specific discipline's jargons and communicate it to the court in understandable, useful or admissible form. Either attorney in a dispute may hire the forensic expert consultant to advice on the facts, issues and strategies of a specific case. The consultant's thoughts and opinions are also often incorporated into the attorney's legal strategy and he need not testify in court nor the product of their work disclosed to opposing counsel. This is however done with utmost due care and confidentiality. The consultant may advise on the most effective way to present these facts at trial based on the strengths and weaknesses of the opposing party's case, analyze their arguments and verify amounts claimed or valuations made and so on. Another area of input by the expert consultant is that he may be engaged to help provide specific questions that will help the case of the client.

2.3.2 Expert Witness; The forensic accounting expert witness plays a more direct role in the prosecution of fraud cases and is considered one of the major roles of the forensic accountant (AICPA, 2014). According to the AICPA (2014), "a person designated to render opinion(s) before a trier of facts is an expert witness". They also alluded that "if designated as an expert witness, the practitioner's litigation-related work may be required to be produced to opposing parties through a process called discoveries". This therefore introduces a new perspective to the duties of the forensic accountant in fraud cases as it introduces direct participation of the forensic accountant as an expert witness. It also implies that there is now an additional attention or skill set needed for carrying out this responsibility as it concerns the courts and court processes. As a matter of fact, the AICPA (2014) gave some of these considerations as to skill sets and needed knowledge of court issues. According to the body the expert witness should comply with "Federal Rules of Evidence"; Rule 702, 703, 704, 705, 706 and the Federal Rules of Civil Procedures, meaning the expert witness must possess a good knowledge of court processes and procedures. Although there are no independent established bodies administrating solely Forensic Accounting practices in Nigeria, the equivalent to the rules given by the AICPA in Nigeria would be the Federal Republic of Nigeria Evidence Act, 2011. Particularly important is section 68(1) where the law makes reference to special knowledge, and that "a judge does not include special skills in science and art. It is conducive to common sense therefore that the opinion of an expert is desirable when such a matter arises...for justice to be done" (Osadolor, 2004). This we may say to mean that the law itself recognizes that the forensic accountant can indeed in his role as an expert witness be a essential factor in the successful prosecution of fraud case.

According to Leauanae and Rasmussen (2004), the expert makes his input by using his investigative accounting skills, helping with; loss calculations and business valuations coupled with his wealth or years of practical experience. Enofe, Odigie, Onayase and Omokhaule (2015) also attested to the role of the forensic accountant as an important role in litigating financial fraud cases. According to them, "many attorneys need assistance from accountants during the preparation of their cases and then later need accountants to testify as expert witnesses". Sanchez and Zhang (2012) attributed the success in nailing tax defaulters or as was reported; people committing tax fraud, to the involvement of the expert witnesses. An opinion or position reverberated by Muehlmam, et. al., 2012.

2.3.3 Special Masters; is one of the litigation roles engaged in by the forensic accountant (AICPA, 2014). There is however little literature available on this particular service. The AICPA (2014), suggested the special master to be another role in which a forensic accountant may be engaged in a litigation process. Although, his responsibility in this regard according to the body is for alternative dispute resolution, it also calls him a court 
appointed expert. Muehlmann et. al. (2015) asserted that the special masters role may be called on by the court at any stage of a litigation; pre-trial, trial and post-trial. Hence in a fraud case, the court also reserves its right to call an expert, in which case he serves as special masters (AICPA, 2014). According to AICPA (2014) the Role of the special masters concerned with the Federal Rules of Evidence, Rule 706 as it deals with experts appointed by the court and Section 53 of the Federal Rules of Civil Procedure (Muehlmann et al, 2015). We may deduce that there is a need for the services of the forensic accountant in this capacity and therefore, the special masters may influence the outcome of a fraud case or execution of a ruling or judgment. The court has over the years increased the use of special masters owing to the result gotten from resolving litigation cases (Muehlmann et. al., 2015).

\subsection{Methodology}

The Objective of this paper is to establish an empirical backing to the effect of the litigation services of a forensic accountant in the adjudication of fraud cases. We administered a well-structured likert scale questionnaire randomly to a target sample consisting of legal practitioners and accountants (AICPA, 2010); to have a controlled sample consisting 20 legal practitioners and 20 Accountants out of a targeted frame of 50 in total (Enofe, Odigie, et al. 2015). More attention was paid to years of experience and knowledge of the subject matter; which all served as control questions and our set criteria (Section B of Questionnaire) for the required sample, Bancroft \& Husen, 2014; Leauanae and Rasmussen, 2004 suggested prior experience to be perhaps the most important characteristic of an effective expert. In line with that, the assumption was that the services or the forensic accountant as implied in this paper would be one carried out by a qualified and experienced forensic accountant. The population mean was applied in testing the hypotheses using One sample T-Test. All analysis was carried out using IBM SPSS Statistic [Version 22] unless otherwise stated.

\subsection{Data Presentation, Analysis and Findings}

Table 1: Participants Demographic Characteristics, Frequencies and Percentages

\begin{tabular}{|c|c|c|c|c|c|}
\hline Case & \multicolumn{3}{|l|}{ Label } & Frequency & Percentages \\
\hline \multirow[t]{2}{*}{ Gender } & \multicolumn{3}{|l|}{ Female } & 3 & 7.5 \\
\hline & \multicolumn{3}{|l|}{ Male } & 37 & 92.5 \\
\hline \multirow[t]{4}{*}{ Age } & \multicolumn{3}{|l|}{ Below 25} & 1 & 2.5 \\
\hline & \multicolumn{3}{|l|}{$26-35$} & 6 & 15 \\
\hline & \multicolumn{3}{|l|}{$36-45$} & 22 & 55 \\
\hline & \multicolumn{3}{|l|}{46 and above } & 11 & 27.5 \\
\hline \multirow[t]{3}{*}{ Qualification } & \multicolumn{3}{|l|}{ Bachelor's } & 36 & 90 \\
\hline & \multicolumn{3}{|l|}{ Master's } & 3 & 7.5 \\
\hline & \multicolumn{3}{|l|}{ Doctorate } & 1 & 2.5 \\
\hline \multirow{3}{*}{ Other Qualifications } & \multicolumn{3}{|c|}{$0-1$ Oualifications } & 34 & 85 \\
\hline & \multirow[b]{2}{*}{$\begin{array}{l}\text { ACFE } \\
\text { CPA } \\
\text { AICPA } \\
\text { BL } \\
\text { ADR } \\
\text { Other }\end{array}$} & \multicolumn{2}{|c|}{$2-3$ Qualifications } & 1 & 2.5 \\
\hline & & \multicolumn{2}{|c|}{ 4-5 Qualifications } & 5 & 12.5 \\
\hline \multirow[t]{5}{*}{ Work Experience } & \multicolumn{3}{|l|}{$0-5$} & 1 & 2.5 \\
\hline & \multicolumn{3}{|l|}{$6-10$} & 7 & 17.5 \\
\hline & \multicolumn{3}{|l|}{$11-15$} & 22 & 55 \\
\hline & \multicolumn{3}{|l|}{$16-20$} & 7 & 17.5 \\
\hline & \multicolumn{3}{|l|}{ Over 21} & 3 & 7.5 \\
\hline \multirow[t]{2}{*}{ Specialty } & \multicolumn{3}{|l|}{ Accountant } & 20 & 50 \\
\hline & \multicolumn{3}{|l|}{ Legal Practitioner } & 20 & 50 \\
\hline \multirow[t]{10}{*}{ Knowledge of subject matter } & \multirow{2}{*}{\multicolumn{2}{|c|}{ Fraud Cases }} & Yes & 40 & 100 \\
\hline & & & No & 0 & 0 \\
\hline & \multirow{2}{*}{\multicolumn{2}{|c|}{ Use of Forensic Accountant }} & Yes & 38 & 95.0 \\
\hline & & & No & 2 & 5.0 \\
\hline & Expert Consultant & & Yes & 38 & 95.0 \\
\hline & & & No & 2 & 5.0 \\
\hline & Expert Witness & & Yes & 37 & 92.5 \\
\hline & & & No & 3 & 7.5 \\
\hline & Special Masters & & Yes & 36 & 30 \\
\hline & & & No & 4 & 10 \\
\hline
\end{tabular}

Source; Authors compilation, 2016

The table above shows results from first two sections of the questionnaire (Section A and section B). The 
frequencies and percentages are also given. The sample was a combination of $50 \%$ Accountants and $50 \%$ legal practitioners. All of which had knowledge of fraud cases and the use of forensic Accountants in fraud cases but for $10 \% .90 \%$ were aware of the job of the expert consultant, $92.5 \%$ were aware of that of the expert witness and $82.5 \%$ answered to the affirmative of their knowledge of the forensic accounting special masters. The corresponding frequencies are given in the table above along with information on the gender distribution as well as age, qualifications and work experience.

\section{Table 2; Descriptive for forensic Expert Consultant} Descriptive Statistics

\begin{tabular}{|c|c|c|c|c|c|}
\hline & $\mathrm{N}$ & Minimum & Maximum & Mean & $\begin{array}{l}\text { Std. } \\
\text { Deviation }\end{array}$ \\
\hline $\begin{array}{l}\text { Forensic Accountant help in discoveries phase of fraud } \\
\text { cases } \\
\text { a forensic accountant helps in investigating fraud } \\
\text { a forensic accountant helps detect fraud and those } \\
\text { involved } \\
\text { A forensic acccountant help quantify losses and damages } \\
\text { Forensic Accounting services key to winning fraud cases } \\
\text { Valid N (listwise) }\end{array}$ & $\begin{array}{l}40 \\
40 \\
40 \\
40 \\
40 \\
40\end{array}$ & $\begin{array}{l}2 \\
4 \\
2 \\
2 \\
2\end{array}$ & $\begin{array}{l}5 \\
5 \\
5 \\
5 \\
5\end{array}$ & $\begin{array}{l}4.58 \\
4.92 \\
4.88 \\
4.70 \\
4.80\end{array}$ & $\begin{array}{l}.813 \\
.267 \\
.516 \\
.648 \\
.608\end{array}$ \\
\hline
\end{tabular}

Source; IBM SPSS Statistic [Version 22], 2016.

The above shows the descriptive results of the analysis done for forensic expert consultant. Five questions were used to test for the effect of the forensic accounting expert consultant on fraud cases and an overall means of 4.776 was gotten by adding all the means and dividing by 5 . The individual means $(4.58,4.92,4.88,4.70$ and 4.80) show that there is very little deviation from the calculated mean of 4.776. This implies that there is an agreement between respondents of effect of the forensic accounting expert consultant on fraud cases. This position is further emphasized by the corresponding standard deviations.

\section{Table 3 Descriptive for Forensic Accounting Expert witness}

\section{Descriptive Statistics}

\begin{tabular}{|c|c|c|c|c|c|}
\hline & $\mathrm{N}$ & Minimum & Maximum & Mean & $\begin{array}{l}\text { Std. } \\
\text { Deviation }\end{array}$ \\
\hline Forensic accounting helps gather evidence of fraud & 40 & 4 & 5 & 4.93 & .267 \\
\hline $\begin{array}{l}\text { Expert witness report is admissible as evidence in fraud } \\
\text { cases }\end{array}$ & 40 & 3 & 5 & 4.78 & .530 \\
\hline $\begin{array}{l}\text { forensic accoutnant may give expert opinnion or witness in } \\
\text { a fraud case }\end{array}$ & 40 & 3 & 5 & 4.73 & .506 \\
\hline Valid N (listwise) & 40 & & & & \\
\hline
\end{tabular}

Source; Source; IBM SPSS Statistic [Version 22], 2016

The table above shows the descriptive results for forensic accounting expert witness. The 3 questions were used to test for effect of the Forensic Accountant's duty as an expert witness. A large percentage of the respondent were aware of the expert witness role and by their response agreed that there was a strong and positive relationship between the services of the expert witness and adjudication of fraud cases. The total mean for this section was 4.813; gotten by adding all the individual means of 4.93, 4.78 and 4.73 and dividing by 3 .

Table 4; Descriptive for Forensic Accounting Special Masters

Descriptive Statistics

\begin{tabular}{|l|l|l|l|l|l|}
\hline & $\mathrm{N}$ & Minimum & Maximum & Mean & $\begin{array}{l}\text { Std. } \\
\text { Deviation }\end{array}$ \\
\hline $\begin{array}{l}\text { Special masters may help the judge in understanding } \\
\text { evidence of litigating parties } \\
\text { special masters may assist in post-trial valuations }\end{array}$ & 40 & 2 & 5 & 4.78 & .660 \\
Valid N (listwise) & 40 & 3 & 5 & 4.83 & .446 \\
\hline
\end{tabular}

Source; fieldwork, 2016

Above is the result for the descriptive on responses of the respondents on the Forensic Accounting Special

Master and fraud cases. The mean of this section was 4.805; gotten by adding the individual means of 4.78 and 4.83 and dividing by 2 . This also shows that there is a strong and positive relationship between the Special Masters role and litigation of fraud cases. 
Table 5 and 6, Reliability Test

Reliability

Scale: Effect of Forensic Accountant's litigation services on Fraud Case

Reliability Statistics

\begin{tabular}{|l|l|}
\hline Cronbach's Alpha & N of Items \\
\hline .758 & 3 \\
\hline
\end{tabular}

Source; IBM SPSS Statistic [Version 22], 2016

Item-Total Statistics

\begin{tabular}{|l|l|l|l|l|}
\hline & $\begin{array}{l}\text { Scale Mean if } \\
\text { Item Deleted }\end{array}$ & $\begin{array}{l}\text { Scale Variance } \\
\text { if Item Deleted }\end{array}$ & $\begin{array}{l}\text { Corrected } \\
\text { Item-Total } \\
\text { Correlation }\end{array}$ & $\begin{array}{l}\text { Cronbach's } \\
\text { Alpha if Item } \\
\text { Deleted }\end{array}$ \\
\hline Forensic_Accounting_Expert_Consultant & 9.6083 & .447 & .681 & .566 \\
Forensic_Accounting_Expert_Witness & 9.5750 & .642 & .554 & .750 \\
Forensic_Accounting_Special_Masters & 9.5833 & .363 & .621 & .680 \\
\hline
\end{tabular}

Source; IBM SPSS Statistic [Version 22], 2016

The table 5 and above is to measure the properties of our measurement scale. The mean of each response was generated for all the respondents and then categorized into our 3 variables of interest. Table 5 gives the Cronbach's reliability result of .758. The ideal Cronbach coefficient is about 0.7 (Pallant as cited in Modugu \& Anyaduba, 2013). The Cronbach coefficient of .758 as gotten above therefore indicates that the instrument of measurement show a high measure of internal consistency, meaning they are appropriate for carrying out further analysis. Table 6 gives the item total statistics; the Cronbach Alpha figure is to indicate if there is any significant improvement to our model by deleting one variable or another, as indicated by the means, of 9.6083, 9.5750, 9.5833 and their corresponding Cronbach Alpha figures of less than 1 there is no significant difference if variables are altered or deleted.

T- Test

One-Sample Statistics

\begin{tabular}{|l|l|l|l|l|}
\hline & $\mathrm{N}$ & Mean & Std. Deviation & Std. Error Mean \\
\hline Forensic_Accounting_Expert_Consultant & 40 & 4.7750 & .40048 & .06332 \\
Forensic_Accounting_Expert_Witness & 40 & 4.8083 & .28130 & .04448 \\
Forensic_Accounting_Special_Masters & 40 & 4.8000 & .49094 & .07763 \\
\hline
\end{tabular}

Source; IBM SPSS Statistic [Version 22], 2016

One-Sample Test

\begin{tabular}{|c|c|c|c|c|c|c|}
\hline & \multicolumn{6}{|c|}{ Test Value $=3$} \\
\hline & \multirow[b]{2}{*}{$\mathrm{t}$} & \multirow[b]{2}{*}{ Df } & \multirow[b]{2}{*}{ Sig. (2-tailed) } & \multirow{2}{*}{$\begin{array}{l}\text { Mean } \\
\text { Difference }\end{array}$} & \multicolumn{2}{|c|}{$\begin{array}{l}95 \% \text { Confidence } \\
\text { Interval of the } \\
\text { Difference }\end{array}$} \\
\hline & & & & & Lower & Upper \\
\hline Forensic_Accounting_Expert_Consultant & 28.032 & 39 & .000 & 1.77500 & 1.6469 & 1.9031 \\
\hline Forensic_Accounting_Expert_Witness & 40.657 & 39 & .000 & 1.80833 & 1.7184 & 1.8983 \\
\hline Forensic_Accounting_Special_Masters & 23.188 & 39 & .000 & 1.80000 & 1.6430 & 1.9570 \\
\hline
\end{tabular}

Source; IBM SPSS Statistic [Version 22], 2016

The above tables are the results of a T-Test carried out to test our analysis. The $\mathrm{P}$ value is the criteria of significance and the decision rules is that if the $\mathrm{P}$ value is less than 0.05 you reject Null.

From the results above, we observe that Ho 1; Forensic accounting Consultant services does not affect fraud cases has a $\mathrm{P}$ value less than 0.05 at a $95 \%$ confidence level; therefore, we reject the Null and assume there that the services of the Forensic accountant in the capacity of an expert consultant does affect the adjudication of fraud and fraud related cases. This is in line with our apriori expectation and agrees with literature reviewed earlier.

We can also observe that Ho2; Forensic accounting expert witness service does not affect fraud cases, has a $\mathrm{P}$ value of .000 at $95 \%$ of confidence which is less than 0.05 , meaning we reject the null. This position agrees with our prior expectations and literatures reviewed.

Lastly, Forensic accounting special masters service does not affect fraud cases, has a $\mathrm{P}$ value of less than 0.05 at a 95\% confidence level. This means that we reject the null and assume that the special master's responsibility or litigation service of a forensic accountant does indeed affect litigation. 


\subsection{Conclusion}

Hopwood, Young and Leiner (2013) said "apart from preventing fraud and obtaining court-ordered restitution, punishing fraudsters may have little economic benefit to the entity...if enough fraudsters are punished, the overall incidence of fraud may be reduced". In attempting to throw more light on successful fraud persecution, it is important that the roles of experts are highlighted, more so for developing countries like Nigeria. We recommend that in prosecuting fraud cases, the forensic accountant's roles as consultant, expert witness and special masters should be engaged. It is our believe that this will play a positive role in tackling the menace of fraud. Asides from serving as a deterrent, it will help get back revenues in the shortest time possible. Cases will be built more accurately and Justice dispensed more efficiently and effectively. The government should be looking at structuring the practice and standardizing or making guidelines that will ensure effectiveness.

For further studies, research may be carried out to ascertain the degree of effect the use of forensic experts may have in litigation. The sample size may also be more diverse to include more magistrates or judges as well as victims of fraud or even fraudsters. The sample composition may also be assessed and analyzed individually to spot any asymmetry of response from the legal practitioner or accountant and so on.

"Though the role of the forensic accountant will vary from case to case, the experience and expertise they bring to the attorney in helping to put together or defend a case can often prove to be immeasurably valuable. In many instances, a reliable expert is one of the first people the attorney calls when setting up his or her team" Elmore (2016)

\section{References}

Adeleh, A. (2014). Analysis of the necessity to develop the Forensic Accounting in Iran. Advances in Environmental Biology, 8(19), pp.170-173.

Albrecht, W. S., Albrecht, C. O., Albrecht, C. C. \& Zimbelman, M. F. (2011). Fraud Examination

American Institute of Certified Public Accountant (2007). Business valuation and Forensic \& Litigation Services Section. Forensic Accounting-Fraud Investigation

American Institute of Certified Public Accountant (2014). Forensic \& Valuation Services Practice Aid. Serving as Expert Witness or Consultant.

Association of Certified Fraud Examiners. (2016). Report to the Nations on Occupational Fraud and Abuse.

Azih, N. \& Okoli, B. E. (2015). Forensic Accounting as a Veritable Tool for Efficient Management of State Owned Public Sectors in Ebony State: The Accountant's Perspective. British Journal of Education, 3(8).

Bancroft, C. \& Husen, D. (n.d) Dispute Resolution: the Role of Forensic Accountants and Computer Forensics.

Dada, S. O., Owolabi, S. A. \& Okwu, A. T (2013). Forensic Accounting a Panacea to Alleviation of Fraudulent Practices in Nigeria. Retrieved from www.ijbmer.com

Ehioghiren, E. E. \& Atu, O. O. K. (2016). Forensic Accounting and Fraud Management: Evidence from Nigeria. Igbinedion University Journal of Accounting, 2.

Elmore, D. (2016). The Role of a Forensic Accountant as an Expert Consultant and an Expert Witness. Retrieved from http://mdd.com/forensic-accounting-articles/the-role-of-a-forensic-accountant-as-an-expertconsultant/

Enofe, A. O., Julius, O. M. \& Ogbeide, O. I. (2015). The Role of Forensic Accounting in Combating Financial Crimes. Research Journal of Finance and Accounting, 6 (18).

Enofe, A. O., Odigie, A, O., Onoyase, A. O. \& Omokhaula, O. P. (2015). Expert Witness and Court System. Developing countries studies, 5 (2)

Enofe, A. O., Okpako, P. O., \& Atube, A. N. (2013). The Impact of Forensic Accounting in Fraud Detection. European Journal of Business and Management, 5 (26)

Federal Bureau Investigation (2012). Forensic Accountants. Retrieved from https://www.fbi.gov/news/stories/fbi-forensic-accountants

Federal Bureau Investigation (2015). Investigating Insurance fraud. Retrieved from https://www.fbi.gov/news/stories/investigating-insurance-fraud

Financial Fraud Action UK. (2015). Fraud the Facts. The definitive overview of payment industry fraud and measures to prevent it.

Golden, W. T., Dyer, T. M., \& Andreassen, S. (2006). Working with Attorney. New Jersey: John Wiley and Sons.

Hopwood, W., Young, G. \& Leiner, J. (2013). Forensic Accounting and Fraud Examination

Leauanae, J. L. \& Rasmussen, D. G. (2004). Expert Witness Qualification and Selection

Modugu. K. P. \& Anyaduba, J. O. (2013). Forensic Accounting and Financial Fraud in Nigeria: An Empirical Approach. International Journal of Business and Social Science, 4 (7)

Okoye, E. I. \& Gbegi, D. O. (2013). Forensic Accounting: A Tool for Fraud Detection and Prevention in the Public Sector. (A Study of Selected Ministries in Kogi State). International Journal of Academic Research in Business and Social Science, 3 (3). 
Olukowade, E \& Balogun, E (2015). Relevance of Forensic Accounting in the Detection and Prevention of Fraud in Nigeria. Historical Research Letterer,23.

Popoola, O. M. J., Che-Ahmed, A., \& Samsudin, R., S. (2014). Impact of Task Performance Fraud Risk Assessment on Forensic Skills and Mindset: Experience from Nigeria. International Journal of Business and Social Science, 5(9).

Sanchez, M. H \& Zhang, S. W. (2012). The Role of the Expert Witness in Accounting Fraud Cases. Global Journal of Business Research, 6(1). 